its lines, providing them with the latest literature on every subject which may be of interest to them, arranges conferences and demonstrations at convenient centres to which large attendances are assured through free travelling facilities, visits to other countries to study the conditions prevailing there, and also provides free carriage on their system for chemicals and spraying apparatus. The conferences are not confined to university professors and researchers in phytopathology, but the chemist and physicist, the manufacturer and the engineer take their place beside the practical man. Lively discussions result from such a gathering of experts, and not unusually the grower is able to hold his own. We were particularly struck by the keenness of the grower in everything pertaining to spraying, and whatever may be the opinion prevailing in Great Britain as to its value, there can be no doubt that the French agriculturalist is a firm adherent to the practice.

The phytopathological is but one side of the work carried out by the P.L.M. Railway. Since I9I2 it has founded ${ }^{3} 8$ experimental nurseries for the training of the peasants, and also many school gardens, subsidised largely the research station at St. GenisLaval and the Insectary at Mentone, experimented with many varieties of strawberries, established a nursery for growing cypress for hedging, and distributed hundreds of thousands of plants free, fruit trees, vines, black currants, asparagus, artichokes, tomatoes, and osiers being the chief, but potatoes and winter vegetables have also received their share of attention. In addition pisciculture, viticulture, and sericulture owe much to the liberality and the encouragement of the Company. A huge organisation and a well-filled purse have always been behind these movements. What is the result to the Company? In I9 Io it carried $x 90,000$ tons of fruit and vegetables, in I 925 this had grown to $488,85^{\circ}$ tons, so that the results of its labours are reflected in the balance-sheet at the end of the year in such a way as to encourage the Company to continue in the work which they are doing with such conspicuous success. L.

\title{
A British Expedition to the Sepik River, New Guinea.
}

$\mathrm{A}^{\mathrm{N}}$ expedition has been planned and is now being of which is to penetrate to the central mountain chain of New Guinea and locate the head-waters of the Sepik River. There is at present a theory that a large lake lies between the Victor Emmanuel Range to the north and the Müller Range to the south, which feeds both the Sepik and the Fly Rivers. In I89I Sir William MacGregor reached a point on the Fly River in the territory of Papua at lat. $8^{\circ} \mathrm{I} \mathrm{I}^{\prime} \mathrm{S}$., long. $\mathrm{I}_{4} \mathrm{I}^{\circ} 54^{\prime} \mathrm{E}$., and of recent years a number of explorations of the head-waters of the Fly River have been carried out by officers in the Papuan service. In I9I3-I4 Dr. Behrman's expedition proceeded up the Sepik River in what is now mandated territory and the advance party reached lat. $8^{\circ} \mathrm{II}^{\prime} \mathrm{S}$., long. $141^{\circ} 36^{\prime} \mathrm{E}$. in the Victor Emmanuel Range, but failed to attain the objective of the expedition, the source of the river. A survey was made up to the point reached by the advance party.

The object of the present expedition will be not only to locate the source of the Sepik, but also to cross and survey the country lying between the headwaters of this river and those of the Fly. Geological, anthropological, zoological, and botanical observations will be made on the way, and if the objective is attained, should lead to results of great importance, as the higher and hitherto unexplored parts of the central mountain chain should produce much new and valuable material in each of these branches of science.

The expedition will proceed by launch to the highest possible point on the Sepik, where a base will be formed. From this the main party will proceed into the hills. Should they succeed in reaching the Fly, they will return down this river, the base party returning down the Sepik independently. The base party will be in communication with the authorities at Rabal by radio, and the main party will keep in touch with the base by means of a small transmitting set. A kinematograph outfit will also be carried.

The personnel of the expedition so far as arranged at present consists of Mr. V. A. C. Findlay, leader and agricultural and topographical surveyor; Mrs. Findlay, engineer, radio operator and photographer; Mr. A. J. Hill, engineer and radio operator; Mr. K. H. Henderson, zoological and botanical collector; Mr. W. S. Malcolm, anthropologist; and Mr. C. T. Teychenné, geological surveyor.

The expedition has received the approval of the Royal Geographical Society, the Royal Anthropological Institute, and the Committee for Anthropology of the University of Oxford. The expedition is being organised under the direction of a council of which Lord St. John of Bletso is president, and Mr. Henry Balfour, The Hon. Mr. H. A. Casson, and Dr. A. F. R. Wollaston, are members. At the recent meeting of the British Association at Oxford a committee was appointed to co-operate in the work of organisation. The estimated cost of the expedition is 6oool., and contingently on that amount being raised, the expedition will leave England in the autumn of 1927 .

\section{The Pelagic Young of the Cod. ${ }^{1}$}

\begin{abstract}
M R. MICHAEL GRAHAM and Mr. J. N. Carruthers have attempted to correlate the known distribution of the pelagic young of the cod with the theoretical distribution deduced from three factorsmarket statistics, wind records, and experiments with drift-bottles. The theoretical part is undertaken by Mr. Carruthers, the practical part, dealing with the actual catches of the young fishes, by Mr. Graham. In addition $\mathrm{Mr}$. H. H. Goodchild investigated the food of the fry from the same samples. Three questions

1 "The Distribution of Pelagic Stages of the Cod in the North Sea in r924 in Relation to the System of Currents," by Michael Graham 1924 in Relation to the System of Currents," by Michael Graham
and $\mathrm{J}$. N. Carruthers. With a section on "The Food of Pelagic Young Cod" by H. H. Goodchild, Fisheries Laboratory, Lowestoft. Ministry of Agriculture and Fisheries. Fishery Investigations, Series 2, vol. 8 , No. 6, r925. London: H.M.S.O.
\end{abstract}

NO. 2966, VOL. I I 8$]$ are involved in the present paper: First, to what extent the drift affects the pelagic fry in the North Sea; secondly, what is the distribution of the fry; and thirdly, what is the food of the young in the pelagic stage ? To answer these questions the market statistics were used to ascertain the spawning-grounds and times, the methods being justified by previous work of one of the authors in r924. A system of cruises was undertaken to fish for the larvæ and postlarvæ from these spawning-grounds outwards; experiments with drift-bottles were made and wind statistics consulted. The ascertained distribution was then compared with the theoretical distribution, and the results were found to be so much in agreement that the authors seem to be justified in their con- 
clusion that the pelagic young of the cod are to a large extent carried by currents.

The method of fishing was by taking oblique hauls with Petersen's young fish-trawl, at first as close to the bottom as possible for ten minutes; then to shorten the warp to half the length used in fishing near the bottom, and tow for a further ten minutes; finally, to tow for ten minutes at the surface. It was not intended to investigate the distribution by depth but to obtain representative hauls from near the bottom to the surface. Thus the fishes from all three depths were mixed together in the sample. In the driftbottle experiments those at the surface only were taken into account. Information as to the vertical distribution of the pelagic young and the vertical extent of the drift would be extremely interesting.

More than a thousand of these pelagic stages were investigated for food; the result, as was entirely to be expected, showing that from the time when it begins to feed the young cod's main food is copepods. Copepods are pre-eminently the food of the larva and postlarva at least up to the time of its settling down to demersal life. Mr. Goodchild finds that diatoms are practically of no importance as food, which also is not surprising, judging from our knowledge of the food of other baby gadoids. The presence of the few specimens he mentions is in all probability accidental.

\section{The Haslemere Educational Museum.}

NEW buildings for the Haslemere Educational Museum, founded a generation ago by the late Sir Jonathan Hutchinson, were inaugurated and opened to the public on August 27. He was an original and powerful influence in many ways; in his hobby of making and directing a museum he became a popular benefactor to the beautiful Surrey district where he had his home, and in the development of which into one of the best known areas for scenery, residence and holiday in the radius of fifty miles from London. The Museum, which was formed and arranged with the educational aim predominant of making every exhibit tell its tale to the average person who came to look at it, has until recently been the property of the Hutchinson family. They have now handed it over to a trust under a scheme by which the collection is placed in new buildings, a maintenance endowment fund is being formed, and the committee becomes representative of local and other institutions, which ensure it being widely popular and therefore educational to many.

The scheme owes much in inception and carrying out to the chairman, Dr. Arnold Lyndon, who presided at the ceremony on August 27, when Earl Midleton formally opened the buildings, and Dr. F. A. Bather, keeper of the Department of Geology in the British Museum, unveiled a memorial tablet to the late Sir Jonathan Hutchinson. A large and distinguished company assembled in the beautiful grounds behind the roomy old mansion in the Hig' Street, which with large additions has been most happily transformed into an admirable Museum. These grounds, with the spacious verandah and lecture hall, make the Museum well suited for education gatherings, whether for instruction of classes or by special demonstrations, etc., or (what may be well looked for) to visits from scientific societies, field clubs, and perhaps summer schools and conferences.

An additional interest is added by the fine collection of so-called Peant Arts, the property for some years of the Peasant Arts Guild, having been donated to the Museum and arranged in a special section. From an anthropological and ethnographical point of view, as well as from that of art and handicraft, this collection is important; there is no other in Great Britain made and arranged on the lines familiar to those who have visited Scandinavia and various continental cities where there are folk-museums. This Peasant Arts Section is entirely sympathetic to the aims and ideas of the late Sir Jonathan Hutchinson ; a number of objects which he had collected have come into fitting spaces in this new phase. A great deal is due to Mr. E. W. Swanton, whom Sir Jonathan many years ago appointed as the curator of his Museum, and who, with the aid of Mrs. Swanton, has become a real educational influence in Surrey. This is recognised by the annual grant of the County Council (as Education Authority) to the Museum. Mr. Swanton is a many-sided man, as was the original founder of the Museum, and he may be trusted to carry the Museum on in the fine tradition which it has established.

\section{University and Educational Intelligence.}

A USEFUL guide-book to the universities of Germany has been published by the Akademische Auskunftsamt an der Universität Berlin. This has been compiled by Prof. Karl Remme, Director of the Central Office for Foreign Students in Prussia. It is an attractive volume of 290 pages, profusely illustrated and well arranged, and will be most useful to students proposing to visit Germany. It comprises an historical introduction, a general description of the higher educational system, statistical summaries, and chapters devoted to facilities available for foreign students, the distribution of subjects of study as between the different institutions, conditions for obtaining degrees and diplomas, and very readable descriptions of the university towns.

RESEARCH in progress at the University of Minnesota, July $1924-$ July 1925 , is described in a threehundred-page pamphlet issued by the University's Graduate School. It contains the titles of about a thousand papers published or in the press and short abstracts of a large proportion of them. In addition it contains brief notes on the subjects and purposes of researches, the methods and materials used, and the results so far as available, in cases in which publication of papers has not been decided on. The index is not very satisfactory, names of researchers and classification headings of subjects of research being mixed in one series. If universities would co-operate in the production of annual lists of titles of subjects of research in progress, such lists could scarcely fail to be of considerable utility.

THE National University of Ireland's Calendar for I926 exemplifies the tendency of such annuals to become unwieldy. It contains more than 900 pages, chiefly lists of graduates and university honours. A list of published works and theses submitted for doctorate degrees from I9I I onwards contains about 200 titles and is followed by a footnote requesting professors, lecturers, and graduates to forward to the registrar "full details of publications and research work carried out by them." Of the six travelling studentships, each $200 l$. per annum for two years, announced for competition in 1925, only one was awarded, namely, in pathology. The subjects notified for travelling fellowships to be offered for competition in 1927 are: mathematical science, Irish together with English or French or German, philosophy, one of the three sciences, botany, zoology and geology, and anatomy.

NO. 2966, VOL. I I 8 ] 